\title{
ANALYSIS OF LEAF BLADE AREA AND TOTAL ILLUMINATION INDEXES OF PANICUM MAXIMUM JACQ. CV. ARIES GRASS WITH DIFFERENT NITROGEN RATES FOR SHEEP FEEDING ${ }^{1}$
}

\author{
L. P. R. da Costa $^{1}$; A. L. Moreira ${ }^{2}$; L. R. A. Gabriel Filho ${ }^{3,4,}{ }^{*}$; R. DE O. Souza ${ }^{5}$ C. P. \\ Cremasco $^{3,4}$; F. F. Putti ${ }^{3}$; M. G. M. Chacur ${ }^{6}$ \\ ${ }^{1}$ FATEC - Faculdade de Tecnologia, Presidente Prudente, SP, Brasil \\ ${ }^{2}$ APTA - Agência Paulista de Tecnologia dos Agronegócios, Polo Alta Sorocabana, Presidente \\ Prudente, SP, Brasil \\ ${ }^{3}$ UNESP - Univ Estadual Paulista, Campus de Tupã, Laboratório de Matemática Aplicada e \\ Computacional, Tupã, SP, Brasil \\ ${ }^{4}$ Faculdade de Ciências Agronômicas, UNESP - Univ Estadual Paulista, Botucatu, SP, Brasil \\ ${ }^{5}$ Escola de Engenharia, UFRGS - Univ Federal do Rio Grande do Sul, Porto Alegre, RS, Brasil \\ ${ }^{6}$ UNOESTE - Univ do Oeste Paulista, Laboratório de Reprodução Animal, Presidente Prudente, \\ SP, Brasil
}

\begin{abstract}
Improvement of nutrition of small ruminants increases production and minimizes costs, especially during dry periods. On the other hand, investments in energy and protein foods cause high production costs. An economical alternative lies in investing in fodder production featuring quality and quantity, by lowering costs and maximizing profits of commercial farms. Current research analyzes forage of the pasture grass Panicum maximum Jacq. cv. Aries, fertilized with 200 and $400 \mathrm{~kg}$ of nitrogen per ha/year, and applying Student's $t$ test to compare the effects in pasture development. The best fertilization for quality forage production within the region's climate and for sheep breeding was assessed. There were no significant differences among the different levels of nitrogen with regard to total illumination and leaf area index. Results show that the use of the least amount of fertilizer, i. e. $200 \mathrm{~kg}^{-1} \mathrm{ha}^{-1}$ year, is economically viable, taking into account lower costs in their acquisition, transportation and application.
\end{abstract}

Keywords: pasture management, small ruminants, forage production, Student $t$ test, agribusiness.

\section{ANÁLISE DOS ÍNDICES DE ÁREA FOLIAR E DE ILUMINAÇÃO TOTAL DO CAPIM PANICUM MAXIMUM JACQ. CV. ÁRIES COM DIFERENTES DOSES DE NITROGÊNIO PARA A ALIMENTAÇÃO DE OVINOS}

\section{RESUMO}

Melhorar à alimentação de pequenos ruminantes é uma das formas de aumentar a produção e minimizar os gastos, principalmente em períodos secos. Por outro lado, investimentos

\footnotetext{
${ }^{1}$ Parte deste trabalho foi apresentada no XVI Simpósio de Engenharia de Produção

* gabrielfilho@tupa.unesp.br
} 
em alimentos proteicos e energéticos geram um alto custo de produção. Uma alternativa econômica é o investimento em produção de forragens que possuam qualidade e quantidade, possibilitando a diminuição de gastos, concomitantemente, aumento do lucro nas criações comerciais. Estudou-se a forragem de capim Panicum maximum Jacq. cv. Áries, adubado com 200 e $400 \mathrm{~kg}$ de nitrogênio por hectare ano, aplicando o teste estatístico t de Student para comparar os efeitos no desenvolvimento da pastagem, avaliando a melhor adubação para produção de forragem de qualidade ao clima da região, voltada a criação de ovinos. Foi constatado que entre os níveis de adubação adotados não ocorreu diferenças significativas no índice de iluminação total e no índice de área foliar. Pode-se afirmar, que é viável economicamente a utilização da menor quantidade de adubo, isto é $200 \mathrm{~kg} \mathrm{ha}^{-1}$ ano ${ }^{-1}$, tendo em vista que os gastos com aquisição, transporte e aplicação do mesmo serão menores.

Palavras-chave: manejo de pastagem, pequenos ruminantes, produção de forragens, teste $t$ de Student, agronegócio.

\section{INTRODUCTION}

Pasture is the main feed resource for ruminants in different product animal systems in Brazil. According to SANTOS et al. (2010), pasture-based animal production is one of the most competitive and profitable alternatives in the country. However, it is important to understand the soil/plant/animal management so that an increase in the degradation of pasture area may be avoided and profit occurs.

Preference to pasture in Brazil is bonded to economic factors, climate diversity, species, productivity and quality of pasturelands in several regions of Brazil (SANTOS et al., 2011). It has been estimated that pastures cover approximately 180 million hectares and correspond to more than $20 \%$ of Brazilian territory (IBGE, 1998; ZIMMER et al, 2002), out of which some 90 million hectares are somewhat degraded. Several forage species are used in the formation of pastures, among which the grass Panicum maximum may be underscored due to its high capacity for the production of dry matter and good quality as animal feed. However, lack of adequate management of the grass and replacement of nutrients in the soil has been the main cause of pasture degradation (JUNIOR; MONTEIRO, 2006).
Forage plants are relevant due to their role in animal feed. In fact, $88 \%$ of meat produced in Brazil comes from cattle herds kept exclusively on pasture (PENATI et al.,1999).

The optimization of pasture systems may not be exclusive to the maximization of forage produced or ingested by animals. The plants' characteristics, such as perenniality, fast regrowth after leaf falling, tolerance to the presence of animals (treading) and adequate nutrition rates should also be assessed. Soil compaction is another factor than potentially impairs the development and accumulation of nutrients (CABRAL et al., 2012).

The growth of forage plants and animal produce are restricted by low supply of nitrogen in the soil (CORSI; NUSSIO, 1993). Nitrogen availability in tropical soil is generally inadequate for the needs of the production of dry matter. This fact is due to high requirements of many forage grasses and to the low supply of the nutrient by the mineralization of the soil's organic matter (SYLVESTRE et al., 2012; GOMES et al., 2011; BATISTOTI et al., 2012).

Silva et al. (2012) report that the use of sewage effluents is feasible for the development of the reposition of nitrogen in 
the soil for the production of dry matter, coupled to the non-occurrence of chemical changes.

Nitrogen is highly important in nutrition and in the production of forage grasses. The theme is underscored in several studies since it is the component of numberless organic compounds which is basic to plants' life (MENGEL; KIRKBY, 2001). It actually has a very important participation in the productivity of pastures (WERNER, 1986).

Nitrogenated fertilization is highly relevant to maintain productivity and perenniality, especially in intensive systems when species with high production capacity of dry matter and good feed features are employed.

The use of pastures also constitute one of the most practical and economic forms in the feed of ruminants, especially in the production of sheep and lambs. Ovine herds and production units have recently experienced an increase due to a higher demand in ovine meat, especially lamb, in the great consumption centers such as the Greater São Paulo area and the great cities of the interior of the state.

The municipality of Presidente Prudente, with 207000 inhabitants, distant $560 \mathrm{~km}$ from the capital city São Paulo, has the fourth greatest sheep herd of the state of São Paulo, with an estimated 15,232,000 sheep, approximately $4.5 \%$ of total in the state, and 150 breeders, according to the Instituto Brasileiro Geografia e Estatística (IBGE, 2009). Although the region is highly appropriated for sheep breeding due to extensive pasturelands (1,360,425 ha), according to Donzelli and Carvalho Filho

\section{MATERIALS AND METHODS}

The assay was performed at the Agência Paulista de Tecnologia dos Agronegócios (APTA) in Presidente Prudente SP Brazil, $22^{\circ} 11^{\prime} \mathrm{S}$ and $51^{\circ} 23^{\prime} \mathrm{W}$, $429.29 \mathrm{~m}$ above sea level, mean annual
(2009), the region lacks the technology for sheep breeding.

As a rule, Brazil has a high production capacity of sheep due to increasing consumer market of quality sheep meat which triggers research on pasturelands (PIRES et al., 2000).

Current assay assesses the effects of nitrogen use at 200 and $400 \mathrm{~kg} / \mathrm{ha} /$ year in the production of forage in pastures with Panicum maximum Jacq. cv. Aries, to verify the amount of ideal nitrogen for the climatic conditions of the Alto Sorocabana region in the state of São Paulo, Brazil, for sheep breeding.

Aries grass is an F1 apomictic hybrid cultivar of LSC2 (Sexual Strain of Centaurus) $\mathrm{x}$ Aruana, obtained from the cross-breeding of two accesses Panicum maximum Jacq., featuring a perennial cycle, rugged plant with great capacity of shoots, thin stem, narrow hairless leaves, with a light green color (ALMEIDA et al., 2011). It tolerates badly drained soils. It has an early cycle and is a great producer of seeds, causing constant populations. It is highly diffused among sheep breeders due to its tastiness and digestibility (TAKASHI, 2003). It is a middle size plant, approximately $120-150 \mathrm{~cm}$ high, with fast regrowth after cutting and production of $18-20 \mathrm{t} / \mathrm{ha} /$ year of dry mass, with $10-15 \%$ crude protein and $70 \%$ digestibility. Panicum maximum is a forager plant that may be employed as direct pasture. Plants have fine stalks and a great number of shoots with excellent tastiness. The above features recommend the forage plant for demanding animals such as sheep, horses and recently weaned calves (TAKASHI, 2003).

temperature at $23^{\circ} \mathrm{C}$, oscillating between mean and maximum at $25.5^{\circ} \mathrm{C}$ and mean minimum temperature at $19.5{ }^{\circ} \mathrm{C}$. Air humidity averaged $80 \%$ and mean yearly rainfall of $1,287.7 \mathrm{~mm}$, with well-defined 
dry and wet seasons. According to Köppen's system (KÖPPEN, 1948), climate is subtropical, with dry and cold winters.

The soil of the experimental area is clayey Red-Yellow Latisol, with a slightly wavy relief. Grass cuts were undertaken in January 2008 and readings on SunScan were done. Treatments comprised two groups of nitrogenated fertilization, $200 \mathrm{~kg} / \mathrm{ha} / \mathrm{year}$ and $400 \mathrm{~kg} / \mathrm{ha} / \mathrm{year}$, with three replications. Fertilization had two variables identified as Leaf Area Index (IAF) and Total Illumination (TI). Experiment design consisted of totally randomized blocks, composed of two types of fertilization for each variable, with three measurements in five days, totaling 15 data for each type of index and fertilization.

Pastures were managed with sheep within a rotational lot system, with a pasturing start when plants reached a height where intercepted and captured by the leaf area of the canopy reached $90-95 \%$. Height was established by simultaneous readings with regard to the interception of photosynthetically active radiation (IRFA) in the enclosures, with Sun Scan (Delta-T Cambridge, UK) to measure the forage canopy (Figure 1).

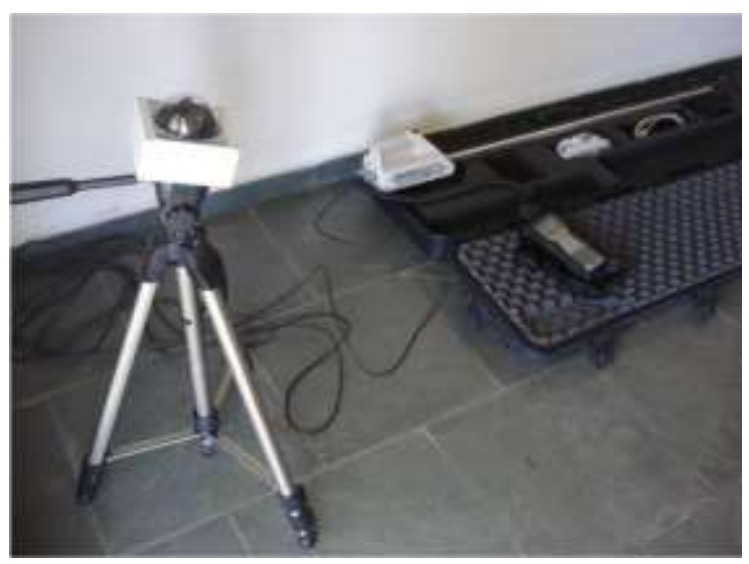

FIGURE 1 - SunScan device

The Sun Scan is composed of three parts: a light sensor that measures radiation on the vegetation; a probe with quantic sensors that measures the radiations transmitted by the canopy and a terminus for data collection that integrates the reading of the first two instruments. Estimates of the interception of photosynthetically active radiation are thus performed.

Seven readings were performed weekly per parcel as from the first pasture, covering a circumference with a 10 -m radius around the point which represents the mean height of the vegetation of the parcels where the radiation sensor tripod was installed.

The minicomputer locked to the computer transfers files of the SunDate program to the Randrive of the computer with My Psion program, with the observation and analysis of data by Microsoft Excel .

Analysis was extended to the test of differences between sample means and fertilizations with regard to variables. Further, $t$ test was applied for independent samples with the following:

$$
t_{\text {Calc }}=\frac{\left(\bar{x}_{A}-\bar{x}_{B}\right)-\left(\bar{\mu}_{A}-\bar{\mu}_{B}\right)}{\sqrt{S_{0}{ }^{2}\left(\frac{1}{n_{A}}+\frac{1}{n_{B}}\right)}},
$$

e

$$
T_{\text {Calc }}=\frac{\left(\bar{x}_{a}-\bar{x}_{b}\right)}{\sqrt{S_{0}^{2}\left(\frac{1}{n_{A}}+\frac{1}{n_{B}}\right)}} .
$$


Test requires the estimate of the common variance between the two populations, called $S_{0}^{2}$, obtained by the weighed mean of sample variances, as follows:

$$
S_{0}^{2}=\frac{\left(n_{A}-1\right) S_{A}^{2}-\left(n_{B}-1\right) S_{B}^{2}}{n_{A}+n_{B}-2} .
$$

Where $S_{A}^{2}$ and $S_{B}^{2}$ are the variants of the two samples under analysis.

In current test, the critical rate is calculated by $g l=n_{A}+n_{B}-2$, where $n_{A}$ and $n_{B}$ are the size of the samples $\mathrm{A}$ and $\mathrm{B}$.

Boxplot graphs were developed with Minitab 15, since its graphic interface provided good visual results similar to the statistical analyses developed in current assay.

\section{RESULTS AND DISCUSSION}

After measuring the indexes IAF and IT, the values for tests $t$ were calculated with Minitab, resulting in $t=0.284$ for IAF and $t=-0.478$ for IT.

Analysis showed that data on fertilization with regard to indexes were not

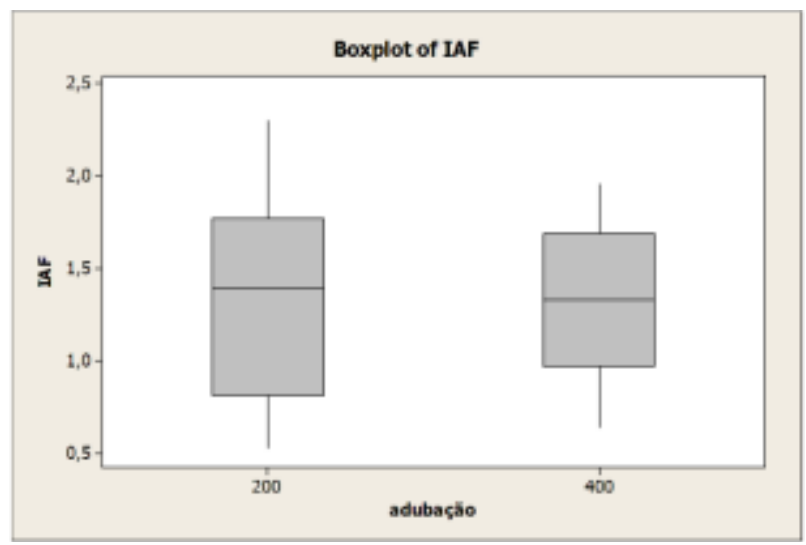

(a) significantly different since $\mathrm{p}$ rates were respectively 0.778 and 0.636 .

A significance level at $\alpha=0.05(5 \%)$ was established. A descriptive analysis of the variables of mean rates and standard deviations was provided for an adequate description of the variables with regard to types of fertilization (Figure 2).

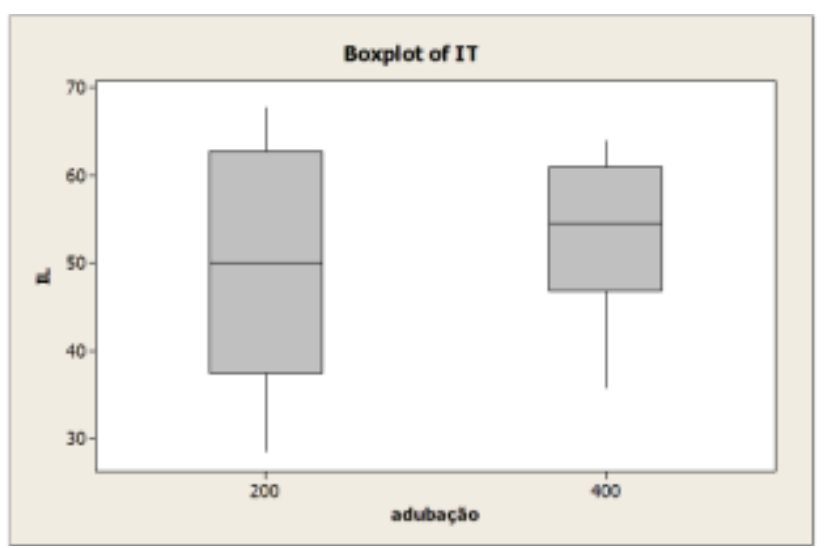

(b)

FIGURE 2 - Boxplot graph for variables IAF and IT.

Figure 2 shows that data median for the variable IAF in $200 \mathrm{~kg}^{-1} \mathrm{ha}^{-1}$ year is 1.39 , whereas for $400 \mathrm{~kg}^{-1} \mathrm{ha}^{-1}$ year it is 1.33 . Data median for the variable IT for measurements for $200 \mathrm{~kg}^{-1} \mathrm{ha}^{-1}$ year is 50.05 and for $400 \mathrm{~kg}^{1} \mathrm{ha}^{1}$ year it is 54.53 .
Means and standard deviation of the variables IAF and IT were employed for the analysis of variance and for the interval of confidence for means (Table 1) with regard to fertilization factors $\left(200 \mathrm{~kg}^{-1} \mathrm{ha}^{-1}\right.$ year and $400 \mathrm{~kg}^{-1} \mathrm{ha}^{-1}$ year), at a $5 \%$ significance level. 
TABLE 1 - Descriptive analysis and confidence interval for means of the variables IAF and IT with regard to fertilization types $200 \mathrm{~kg}^{-1} \mathrm{ha}^{-1}$ year and $400 \mathrm{~kg}^{-1} \mathrm{ha}^{-1}$ year.

\begin{tabular}{cccc}
\hline Variable & Fertilization & Descriptive Analysis & $\begin{array}{c}\text { Interval of confidence } \\
\text { for means }\end{array}$ \\
\hline \multirow{2}{*}{ IAF } & 1 & $1.38 \pm 0.55$ & {$[1.08 ; 1.68]$} \\
\cline { 2 - 4 } & 2 & $1.33 \pm 0.40$ & {$[1.11 ; 1.55]$} \\
\hline \multirow{2}{*}{ IT } & 1 & $50.89 \pm 12.61$ & {$[43.91 ; 57.87]$} \\
\cline { 2 - 4 } & 2 & $52.83 \pm 9.37$ & {$[47.64 ; 58.02]$} \\
\hline
\end{tabular}

It should be underscored that there were no significant differences between IAF and IT with regard to fertilization. The application of $200 \mathrm{~kg}^{-1} \mathrm{ha}^{-1}$ year of nitrogen on the pasture may provide less costs.

\section{CONCLUSIONS}

After studying the characteristics of the grass Aries, a hypothesis was raised on the possible levels of growth with different quantities of nitrogen. Experiments and statistics revealed that different levels of fertilization in region with similar climate features and equivalent soil did not provide any significant differences on the index of

\section{ACKNOWLEDGEMENTS}

The authors would like to thank the Agência Paulista de Tecnologia dos Agronegócios (APTA) of the Polo Alta Sorocabana, Presidente Prudente SP Brazil, for its help in the assays performed; thanks are also due to the Fundação de Amparo à total illumination and on the index of leaf area.

Results show that the use of a small amount of nitrogenated fertilization, 200 $\mathrm{kg} / \mathrm{ha} /$ year, is economically feasible since acquisition, transport and applications costs are lower.

\section{REFERENCES}

ALMEIDA, M. C. C.; CHIARI, L.; JANK, L.; VALLE, C. B. Diversidade genética molecular entre cultivares e híbridos de Brachiaria spp. E Panicum maximum. Ciência Rural, Santa Maria, v.41, n.11, p.1998-2003, nov, 2011.

BATISTOTI, C.; LEMPPA, B.; JANK, L.; MORAIS, M. G.; CUBAS, A. C.; GOMES, R. A.; FERREIRA, M. V. B. Correlations
Pesquisa do Estado de São Paulo (FAPESP) for funding of current research (Process $n$. 06/55786-5) and for the scholarships in technical training (Processes n. 08/11300-8 and 08/11322-0).

among anatomical, morphological, chemical and agronomic characteristics of leaf blades in Panicum maximum genotypes. Animal Feed Science and Technology, v.171, p.173-180,2012.

CABRAL, C. E. A.; BONFIM-SILVA, E.M.; BONELLI, E. A.; SILVA, T. J. A.; CABRAL, C. H. A.; SCARAMUZZA, W. L. M. P.; Compactação do solo e 
macronutrientes primários na Brachiaria brizantha cv. Piatã e Panicum maximum cv. Mombaça. R. Bras. Eng. Agríc. Ambiental, v.16, n.4, p.362-367, 2012.

CORSI, M., NUSSIO, L. G. Manejo do capim-elefante: Correção e adubação do solo. In: Simpósio sobre Manejo de Pastagem, 10, 1993, Piracicaba. Anais... Piracicaba: FEALQ, 1993. p.87-115.

DONZELLI, J. R. G; CARVALHO FILHO, A. A. Estudo da produção de ovinos no ano de 2008 na $10^{a}$ região administrativa do Estado de São Paulo - SP utilizando-se da técnica de estatística multivariada de análise fatorial. In: IV SIMPÓSIO DE MATEMÁTICA, 2009, Presidente Prudente, SP. Anais... Presidente Prudente : UNESP, 2009, p.1-4.

GOMES, R. A.; LEMPP, B.; JANK, L.; CARPEJANI, G. C.; MORAIS, M. G. Características anatômicas e morfofisiológicas de lâminas foliares de genótipos de Panicum maximum. Pesq. Agropec. Bras., Brasília, v.46, n.2, p.205211, fev. 2011.

\section{INSTITUTO BRASILEIRO DE} GEOGRAFIA E ESTATÍSTICA - IBGE. Censo agropecuário. Recenseamento geral do Brasil. Rio de Janeiro: Fundação Instituto Brasileiro de Geografia e Estatística. 1998.

\section{INSTITUTO BRASILEIRO DE} GEOGRAFIA E ESTATÍSTICA - IBGE. Pesquisa da Pecuária Municipal. Available at: <http://www.ibge.com.br>. On 10/01/2013.

JUNIOR, J. L; MONTEIRO, F. A. Diagnose nutricional de nitrogênio no capim aruana em condições controladas. Ciência do Solo, Viçosa, v.30, n.5, p.829-837, 2006.

KÖPPEN, W. Climatologia. Buenos Aires: Gráfica Panamericana, 1948. 478p.
MENGEL, K.; KIRKBY, E. Principles of plant nutrition. 5.ed. Dordrecht/Boston/London: Kluwer Academic Publishers, 2001. 849p.

PENATI, M. A.; CORSI, M.; MARTHA JR. et al. Manejo de plantas forrageiras no pastejo rotacionado. In: SIMPÓSIO GOIANO SOBRE PRODUÇÃO DE BOVINOS DE CORTE, 1999. Goiânia, GO. Anais.... Goiânia: CBNA, 1999.p.123-144.

PIRES, C. C. et al. Cria e terminação de cordeiros confinados. Ciência Rural, Santa Maria, v.30, n.5, p.875-880, 2000.

SANTOS, J. T et al. Atributos físicos e químicos do solo de Áreas sob Pastejo na Micro Região do Brejo Paraibano. Ciência Rural, Santa Maria, v.40, n.12, p.24862492, 2010.

SANTOS, P. M.; SANTOS, A. C.; NEGREIROS NETO, J. V. N.; ARAÚJO, A. S.; SILVA J. E. C. Caracterização de pastagens de capim tanzânia e mombaça consorciados com estilosantes em ecótono de ransição Cerrado: Floresta Amazônica. Revista Brasileira de Ciências Agrárias, v. 6, n.1, jan-mar, pp. 163-173,2011.

SILVA, J. G. D.; MATOS, A. T. DE; BORGES, A. C.; PREVIERO, C. A. Composição químico-bromatológica e produtividade do capim-mombaça cultivado em diferentes lâminas de efluente do tratamento primário de esgoto sanitário. Rev. Ceres, Viçosa, v. 59, n.5, p. 606-613, set/out, 2012.

SYLVESTRE, T. B.; KUHNEN, F.; SILVA, E. R.; MARTINS, P. E .S.;GALATTI, F. S.; PRADO, R. M. Resposta do capim-tanzânia à aplicação de manganês. Biosci. J., Uberlândia, v. 28, n. 5, p. 684-691, Sept./Oct. 2012. 
TAKASHI, A. Novas sementes para pastagens chegam ao mercado pelas mãos da Matsuda. São Paulo, Presidente Prudente, 2003. Available at: <http://www.sinomar.com.br/em_290703.as p>. On 10/01/2013.

WERNER, J. C. Adubação de pastagens. Nova Odessa, Instituto de Zootecnia, 1986. 49p. (IZ. Boletim Técnico, 18).

ZIMMER, A.; SILVA, M. P.; MAURO, R. Sustentabilidade e impactos ambientais da produção animal em pastagens. In: PEIXOTO, A. M.; MOURA, J.C.; PEDREIRA, C. G. S.; FARIA, V. P., eds. Inovações tecnológicas no manejo de pastagens. Piracicaba, FEALQ, 2002. p.3158. 